\section{Herpes Simplex from a Human Bite}

\section{To the Editor:}

In a report by Drs. Fuortes and Melson on a nurse developing a herpes simplex infection following a human bite, ${ }^{1}$ they fail to cite a work by del Rosario et al. on a patient developing a primary herpes simplex virus infection on the side of the neck acquired from a hickey (or "love bite"); the so-called "herpetic hickey."2

Although the risk of receiving a hickey in the health care setting would appear to be low, both cases stress the need for health care workers to he aware of the potential infectivity of all body fluids.

1. Fuortes L, Melson E: Brief report: Primary and recurent herpes simplex infection in a pediatric nurse resulting from a human bite. Infert (embol Hosp Epridemiol 1989; 10:120.

2. Inel Rosario N, Blair E. Rickman L: A herpetic hickey. NEngl J Med 1987:317:54-55.

Leland S. Rickman, MD Bethesda, Maryland

\section{Infection Control Information and Malpractice Cases}

\section{To the Editor:}

We have recently been asked to turn over infection control committee minutes and work sheets that might be relevant to a case of malpractice.

Is there literature on this? Are these activities considered "peer review"?

\section{Charles S. Levy, MD}

Washington, DC .

This question was referred to Harry $C$. Nottebart, Jr., JD, $M D$

The problem raised about hospital infection control committee minutes and work sheets is a difficult one for more than one reason. First, there is no uniform national policy. Each state and the District of Columbia makes its own laws and those laws are interpreted by its courts.

This area of law would be considered evidence. Under evidence are the issues of discovery and admission. If something-a document, minutes, work sheets-is discoverable, the opposing side gets to look at and get a copy of the document in question. Admission is the issue of whether any such evidence can be admitted as evidence at a trial. These are two separate and distinct questions. It is quite possible for a document to be discoverable but not admissible.

In general, courts favor free and open exchange of information and will usually deny a request for discovery only if there is statutory language making, an exception, or granting a privilege, as they would say.

Some states have passed laws protecting all hospital committee records. Other states have passed laws protecting only "peer review" committees. In those latter states, some may decide byjudicial opinion that infection control committees are peer review committees; others may come to the opposite conclusion.

However, even in those states in which there is statutory protection and in which judicial interpretation has protected infection control committee records, courts have been known to reinterpret or "distinguish" a present case from the past precedent so as to give the opposite result. 'Ihere are a couple of D.C. cases like this.

In short, there is no national hard and fast rule, and even in those states in which there seems to be statutory protection and in which the courts have applied this protection or privilege to infection control committee records, one still may find oneself subject to discovery in a specific case if the court distinguishes the facts in the current case from the precedents.

With this in mind, what can one do? The minutes and even work sheets arc, in my opinion, for documentation of facts, not speculations. The minutes also should reflect an active committee seeking to improve patient care, active in educating the staff as to possible risk factors for nosocomial infections and not a committee meeting solely because there is a requirement to do so. If such minutes are then discovered and later admitted as evidence it will reflect an active committee attempting to improve patient care and not involved in some sort of cover-up.

You might see my earlier comments on this issue with several brief case synopses in Infection Control, 1:47-49 (1980) and 5:295-297 (1984).

Harry C. Nbttehart, Jr., JD, MD Richmond. Virginia 